\title{
Potensi Karton Bekas Minuman sebagai Komposit PolyAl-fiber
}

\author{
Andri Taufick Rizaluddin*, Ike Rostika, Reza Bastari Imran Wattimena \\ Balai Besar Pulp dan Kertas, Jl. Raya Dayeuhkolot No. 132 Bandung, Indonesia \\ Diterima : 5 April 2020, Revisi akhir : 30 Mei 2020, Disetujui terbit : 30 Juni 2020 \\ Potential of Used Beverages Cartons for PolyAl-fiber Composite
}

\begin{abstract}
Various recycling processes have been developed to overcome the problem of Used Beverage Carton (UBC) waste. Research was conducted to determine the potential utilization of UBC as a material for more waterproof composite and compared it to similar products. The composites were made using hot press machine at temperature of $165^{\circ} \mathrm{C}$ and pressure of $25-30 \mathrm{~kg} / \mathrm{cm}^{2}$ for 10 minutes with $5 \%-30 \%$ fiber content. The PolyAl-fiber composite obtained had bending strength of $12.78 \mathrm{MPa}$, bending modulus of $11.60 \mathrm{GPa}$, flammability of $3 \mathrm{~cm} / \mathrm{min}$, water absorption of $2.1-14.1 \%$, moisture content of $0.9-1.9 \%$, and density of 0.68-0.94 g/ $/ \mathrm{cm}^{3}$, at thickness of 2.5-3.5 mm. The PolyAl-fiber composite could meet the requirements for fiberboard, particleboard, or plastic wood composite standards without extra additives or treatment to the raw materials, indicating that it could be used for similar purposes. The PolyAl-fiber composites may able to produce a better quality of composite boards, due to their flexible, waterproof, and fire-resistant characteristics compared to similar products made from wood or biomass.
\end{abstract}

Keywords: UBC, PolyAl-fiber composite, water absorption, bending strength

\begin{abstract}
Abstrak
Dalam rangka penanggulangan limbah Karton Bekas Minuman (KBM), telah dikembangkan proses daur ulang untuk mengembalikannya menjadi bahan baku. Tujuan penelitian ini adalah untuk mengetahui potensi pemanfaatan KBM sebagai bahan baku komposit yang lebih tahan air, dan membandingkannya dengan spesifikasi teknis produk sejenis. Pembuatan komposit dilakukan dengan pemanasan menggunakan alat hot press pada suhu $165^{\circ} \mathrm{C}$ dan tekanan $25-30 \mathrm{~kg} / \mathrm{cm}^{2}$ selama 10 menit. Produk komposit yang diperoleh memiliki nilai bending strength $12,78 \mathrm{MPa}$, bending modulus 11,60 $\mathrm{GPa}$, flammability $3 \mathrm{~cm} /$ menit, daya serap air $2,1-14,1 \%$, kadar air $0,9-1,9 \%$, dan rapat massa $0,68-0,94$ $\mathrm{g} / \mathrm{cm}^{3}$, pada ketebalan 2,5-3,5 mm. Komposit PolyAl-fiber dapat memenuhi persyaratan standar papan serat, papan partikel maupun komposit kayu plastik tanpa penambahan bahan maupun proses lain, yang mengindikasikan komposit PolyAl-fiber memiliki potensi untuk digunakan dalam berbagai keperluan sejenis. Komposit PolyAl-fiber akan dapat menghasilkan papan komposit dengan kualitas lebih baik, karena lebih fleksibel, lebih tahan air, dan lebih tahan api bila dibandingkan dengan produk lain yang terbuat dari bahan baku kayu atau biomassa.
\end{abstract}

Kata kunci : KBM, komposit PolyAl-fiber, daya serap air, bending strength 


\section{Pendahuluan}

Konsumsi kemasan makanan dan minuman mengalami peningkatan seiring dengan tersedianya kemasan aseptik yang lebih higienis. Dengan kemasan aseptik, makanan dan minuman dapat bertahan lebih lama tanpa penambahan bahan pengawet. Namun, penggunaan kemasan karton minuman yang meningkat dari tahun ke tahun ini menimbulkan masalah baru berupa limbah kemasan KBM. Dalam rangka penanggulangan masalah ini maka dikembangkan berbagai proses daur ulang untuk mengembalikan limbah menjadi bahan baku papan serat. Penelitian mengenai daur ulang kemasan karton bekas minuman telah dilakukan oleh Balai Besar Pulp dan Kertas (BBPK) sejak 2004. Kemasan KBM terdiri dari 6 (enam) lapisan yang terdiri dari $74 \%$ serat dengan sisanya berupa $21 \%$ Low Density Polyethylene (LDPE) dan 5\% aluminium (Al) foil (Tetra Pak, 2020b, 2020a). Dalam implementasinya, kedua material ini digunakan secara terpisah. Serat sekunder hasil daur ulang dari KBM ini telah berhasil dipisahkan sebagai pulp serat panjang coklat, dan telah dimanfaatkan menjadi bahan baku kertas. Sebagai produsen kertas terbesar ASEAN, Indonesia masih membutuhkan hingga 7 juta ton kertas bekas per tahun sebagai bahan baku, dengan sekitar $60-70 \%$ (4-4,5 juta ton) masih berupa impor (Indonesia Finance Today, 2014; Rini, 2019). Ketersediaan serat panjang coklat dari KBM ini dapat menjadi potensi untuk mendapatkan bahan baku dengan kualitas lebih baik dari pulp kertas bekas. Sementara itu, bahan LDPE-aluminium foil dapat dimanfaatkan sebagai bahan baku atap, partisi dan meubelair (Rizaluddin, Rostika, and Wattimena, 2020). Penggabungan kedua material ini akan menjadi peluang tersendiri dalam menciptakan bahan komposit polimer baru yang implementasinya menjadi lebih luas. Dengan tingkat daur ulang kemasan KBM di Indonesia yang diperkirakan masih mencapai $21,2 \%$ atau 10.338 ton dengan potensi total sekitar 50.000 pada tahun 2018, maka peluang pemanfaatan serat panjang, polietilen (PE) dan aluminium foil masih terbuka (Media Indonesia, 2019). Bila diasumsikan kandungan persentase sesuai dengan angka di atas, maka potensi kandungan serat panjang dapat mencapai 37.000 ton, PE 10.500 ton, serta aluminium foil 2.500 ton pertahun.

Perkembangan material komposit polimer sebagai pengganti logam dan karbon sangat menjadi perhatian, hal ini karena komposit polimer memiliki sifat mekanik yang cukup baik, memiliki sifat isolator panas dan suara, tahan korosi, serta dapat dijadikan sebagai penghambat listrik yang baik selain itu juga ramah lingkungan. Selain itu komposit polimerserat alam (natural fiber-polymer composites/ NFPCS) diperkirakan akan memiliki masa depan yang cerah, dengan meningkatnya jumlah penelitian dan penggunaannya berkembang pada area yang lebih luas. Dengan harga yang murah, mudah terurai di alam, ketersediaan yang luas dan rapat massa yang rendah menjadikan serat alam sebagai bahan penguat yang kovensional pada komposit kaca dan karbon. Namun pada penggunaan yang lebih luas, kualitas komposit polimer-serat alam ini perlu memperhatikan kekuatan mekanik, penyerapan air, densitas, serta sifat termal buruk. Sifat termal berupa uji flammability dapat menjadi acuan untuk melihat karakteristik komposit (Feldbauer, 2014; Molina Grima, Belarbi, Acién Fernández, Robles Medina, and Chisti, 2003).

Saat ini penggunaan material komposit dalam kehidupan sehari-hari sangat bervariasi, misalnya untuk pembuatan peralatan rumah tangga, komponen-komponen mesin seperti casing kapal, mobil maupun sepeda motor yang terbuat dari bahan material komposit polimer. Penggunaan bahan komposit polimer berserat alam dalam bidang industri otomotif saat ini pula mengalami perkembangan yang pesat serta berusaha menggeser keberadaan bahan komposit polimer sintetis yang sudah biasa dipergunakan sebagai penguat pada bahan komposit seperti E-Glass, Carbon, dan Silicone Carbide (Sulaiman and Rahmat, 2018). Penggunaan komposit polimer dalam produksi komponen-komponen mobil telah terbukti mampu menyeimbangkan fungsi mobil seperti mengurangi berat dan menjaga keselamatan penumpang (Ezekwem, 2016).

Terlepas dari implementasi komposit polimer tersebut pada suatu industri tertentu, penelitian ini bertujuan untuk mendapatkan potensi pemanfaatan serat sekunder, LDPE dan aluminium yang berasal dari KBM sebagai produk komposit Polyethylene-Al-fiber (PolyAlfiber) untuk papan serat tahan air dengan membandingkan spesifikasi teknis produk serta daur ulang limbah lain untuk menjadi produk sejenis. Komposit tersebut diperkirakan akan dapat menggantikan produk sejenis yang sekarang digunakan, dikarenakan sifat dari aluminium foil yang lebih fleksibel, lebih tahan air dan lebih 
tahan api bila dibandingkan polimer yang terbuat dari kayu. Selain itu, produk komposit ini juga akan memiliki nilai tambah karena berasal dari daur ulang sampah.

\section{Bahan dan Metode}

\section{Bahan Baku Komposit PolyAl-fiber}

Limbah kemasan KBM (Gambar 1.a) didapatkan dari Unit Inovasi BBPK Bandung yang berasal dari pengumpulan hasil pemilahan sampah di tempat pengumpulan sampah oleh para pemulung. PE dan aluminium foil yang sudah terpisahkan dari KBM (Gambar 1.b) diperoleh dari hasil daur ulang limbah kemasan KBM yang dilakukan pada Unit Inovasi BBPK Bandung.

\section{Perlakuan Awal pada Bahan Baku}

Pada bahan baku LDPE-Al dilakukan pencacahan dengan alat pencacah (crusher). Pada bahan baku KBM yang masih utuh juga dilakukan pencacahan dengan alat yang sama sebagai bahan baku serat. Proses pencacahan dilakukan di laboratorium bahan baku Balai Besar Pulp dan Kertas. Pencacahan KBM menggunakan alat pencacah Willey Mill bertujuan untuk memperoleh bahan serat yang berfungsi sebagai bahan pengisi komposit dan dapat terdistribusi merata pada pelat komposit yang terbentuk, sedangkan penghalusan bahan serat dengan penggilingan terhadap bahan serat KBM yang sudah dicacah bertujuan untuk memperoleh bahan dengan ukuran lebih halus sehingga dapat terdistribusi dengan lebih merata.

\section{Proses Percobaan Variasi Bahan Serat dan Uji Panjang Serat}

Proses penghalusan KBM hasil pencacahan (kode AS pada Tabel 2) dilakukan dengan blender selama 1 menit dan 5 menit. Proses pengujian panjang serat dan distribusi serat dilakukan di laboratorium BBPK berdasarkan SNI 01-18401990 tentang Cara uji panjang serat kayu dan non kayu.

\section{Proses Pembentukan Komposit}

Tahapan pembuatan komposit PolyAl-fiber skala laboratorium diawali dengan pencacahan bahan serat (Gambar 1.c) dan bahan LDPE$\mathrm{Al}$ (Gambar 1.d) yang dilakukan seperti pada perlakuan awal bahan. Penyiapan campuran serat (KBM cacah) dengan LDPE-Al cacah dilakukan dengan melakukan pengadukan, jumlah serat sesuai dengan variasi perlakuan 0 $\%, 5 \%, 10 \%, 15 \%, 20 \%, 25 \%$, dan 30\%. Pelat cetakan yang dilapisi lembaran teflon untuk komposit disiapkan, lalu campuran PolyAlfiber dimasukkan secara merata dalam cetakan, dan ditutup dengan pelat besi. Mesin hot press laboratorium BBPK (Gambar 1.e) disiapkan

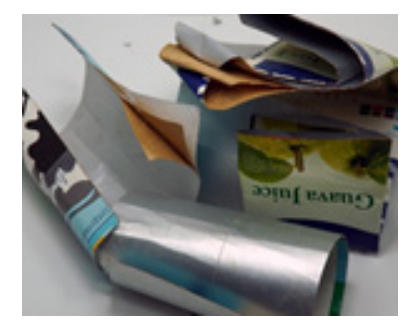

(a) KBM

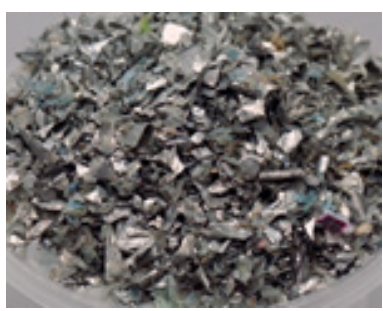

(d) PolyAl setelah dicacah

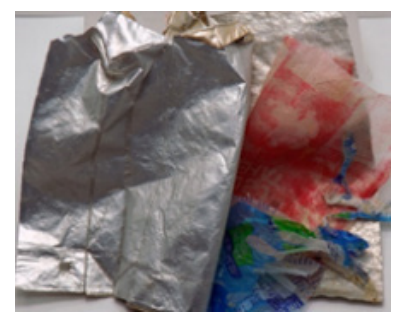

(b) PolyAl (LDPE-Al)

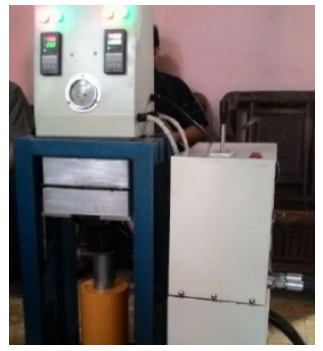

(e) Mesin hot press

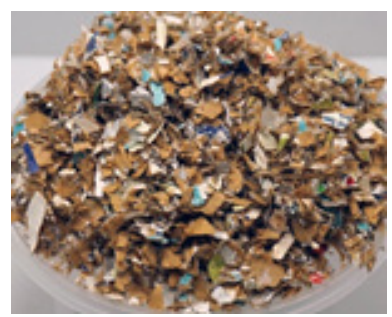

(c) KBM setelah dicacah

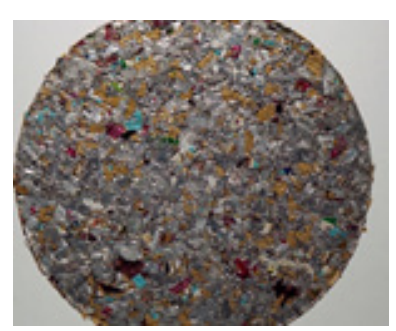

(f) Produk Komposit

Gambar 1. Bahan Baku KBM, Mesin, dan Contoh Produk yang Dihasilkan 
pada suhu yang diperlukan, yaitu $165^{\circ} \mathrm{C}$, dengan pertimbangan temperatur mesin hot press berada di atas titik leleh LDPE yang berada pada $123^{\circ} \mathrm{C}$ (Polymer Properties Database, 2019; Sudiryanto, 2015). Pelat cetakan yang sudah diisi bahan baku komposit berupa campuran PolyAl-fiber lalu disimpan pada pelat besi bagian bawah pada mesin hot press yang sudah dalam keadaan panas. Setelah itu pelat besi mesin hot press bawah dinaikkan sampai pelat cetakan menempel pada pelat besi yang berada di bagian atas pada mesin hot press, cetakan, pelat dan bahan baku tetap ditekan hingga tekanan mencapai $25-30 \mathrm{~kg} / \mathrm{cm}^{2}$ selama 10 menit. Pengepresan dilakukan pada tekanan maksimal dengan tujuan diharapkan dapat menghasilkan papan dengan kerapatan tinggi lebih besar dari $0,84 \mathrm{~g} / \mathrm{cm}^{3}$ sesuai SNI 014449-2006 tentang papan serat. Waktu 10 menit didasarkan pada penelitian sebelumnya bahwa waktu tersebut memberikan properti fisik dan mekanis yang baik (Iswanto, Febrianto, Hadi, and Ruhendi, 2013; Rizaluddin and Setiawan, 2019; Sudiryanto, 2015). Setelah 10 menit, pelat cetakan yang masih berisi campuran PolyAl-fiber yang telah dipres dipindahkan ke meja kerja, 4 pasang baut lalu dipasangkan pada pelat cetakan agar cetakan komposit tidak berubah, dan setelah didinginkan selama minimal 1 jam, diperoleh lembaran komposit yang telah terbentuk .

Pengujian lalu dilakukan terhadap produk komposit PolyAl-fiber (Gambar 1.f) sesuai metoda atau standar yang ada pada Tabel 1. Pengujian sampel komposit dilaksanakan di laboratorium BBPK dan laboratorium polymer
Sentra Teknologi Polimer(STP-BPPT). Komposit pada penelitian ini merupakan bahan dari hasil daur ulang KBM yang terdiri dari serat, LDPE dan aluminium foil, sehingga belum memiliki standar yang dapat diacu, dengan membandingkan dengan SNI dan JIS, diharapkan dapat memberi gambaran pada kualitas yang didapatkan.

Standaryangdigunakanuntukmembandingkan kualitas komposit adalah SNI 03-2105-2006 dan standar Jepang (JIS) A 5908-2003 tentang papan partikel, SNI 01-4449-2006 dan JIS A 59052003 tentang papan serat, serta SNI 8154: 2015 tentang komposit kayu plastik. Selain itu, data hasil uji juga dibandingkan dengan penelitian lain mengenai komposit papan partikel maupun papan serat untuk memperlihatkan perbandingan proses yang dilakukan penelitian ini dengan penelitian lain.

Tabel 1. Pengujian Komposit PolyAl-fiber

\begin{tabular}{lll}
\hline No & Parameter & Metoda \\
\hline 1 & Panjang dan distribusi & SNI 0118401990 \\
& serat & \\
2 & Gramatur & SNI ISO $536: 2010$ \\
3 & Tebal & SNI ISO $534: 2011$ \\
6 & Rapat massa & SNI ISO $534: 2011$ \\
7 & Kadar air & SNI ISO $287: 2009$ \\
8 & Daya serap air & SNI $1970: 2008$ \\
9 & Bending strength \& & ISO 14125 \\
& Modulus & \\
10 & Flammability Test & UL 94 \\
\hline
\end{tabular}

Tabel 2. Hasil Uji Panjang Serat Daur Ulang Kertas Kemasan Aseptik Bekas

\begin{tabular}{clccc}
\hline No & Parameter & AS & 2AB1 & 2AB5 \\
\hline 1 & Panjang serat, max (mm) & 5,01 & 4,26 & 3,59 \\
2 & Panjang serat, min (mm) & 0,81 & 0,53 & 0,46 \\
3 & Panjang serat, rata-rata (mm) & 2,25 & 1,36 & 1,20 \\
4 & Distribusi panjang serat (\%) & & & \\
& $0,2-0,5 \mathrm{~mm}$ & 0 & 0 & 1,00 \\
& $0,5-1,0 \mathrm{~mm}$ & 2,00 & 26,50 & 41,50 \\
& $1,0-2,0 \mathrm{~mm}$ & 48,50 & 65,50 & 49,00 \\
& $2,0-3,0 \mathrm{~mm}$ & 3,00 & 7,00 & 6,50 \\
& $3,0-7,5 \mathrm{~mm}$ & 19,50 & 1,00 & 2,00 \\
\hline
\end{tabular}

Keterangan:

AS: kemasan antiseptik bekas hasil pencacahan

2AB1: AS digiling dalam blender selama 1 menit

2AB5: AS digiling dalam blender selama 5 menit 


\section{Hasil dan Pembahasan}

\section{Bahan Baku Serat Dari Karton Bekas Minuman}

Perlakuan awal pada KBM sebagai bahan serat adalah dengan melakukan pencacahan dan penggilingan, diharapkan agar serat dapat tercampur rata pada komposit yang terbentuk. Variasi perlakuan berupa bahan KBM cacah (kode $\mathrm{AS}$ ), dan 2AB1 dan 2AB5 hasil penggilingan dengan menggunakan blender selama 1 menit dan 5 menit.

Pencacahan KBM (kode AS) bertujuan untuk memperoleh bahan serat yang berfungsi sebagai bahan pengisi komposit dan dapat terdistribusi merata pada pelat komposit yang terbentuk, sedangkan penghalusan bahan serat dengan penggilingan KBM yang telah dicacah (kode $\mathrm{AB}$ ) bertujuan untuk memperoleh bahan dengan ukuran lebih halus sehingga dapat terdistribusi dengan lebih seragam.

Data Tabel 2 memperlihatkan bahwa proses penggilingan justru menyebabkan terjadinya gumpalan serat dan menurunkan panjang serat rata - rata, sehingga menyebabkan komposisi serat panjang menjadi lebih rendah. Hasil pengujian panjang serat yang diperlihatkan pada Tabel 2, memperlihatkan bahwa serat yang paling panjang berasal dari kemasan antiseptik bekas hasil pencacahan (AS). Distribusi panjang serat menunjukkan bahan AS memiliki 48,5\% serat dengan panjang serat sebesar 1,00 sampai 2,00 $\mathrm{mm}$, dan $19,5 \%$ serat dengan panjang $3,0 \mathrm{~mm}$ sampai dengan $7,5 \mathrm{~mm}$, serta $2 \%$ serat dengan panjang serat lebih kecil dari $1 \mathrm{~mm}$. Sementara itu hasil yang diperoleh dari proses menggunakan blender (AB) menunjukkan peningkatan komposisi jumlah serat pada panjang serat yang lebih kecil dari $2 \mathrm{~mm}$, dan yang lebih kecil $1 \mathrm{~mm}$, serta menurunkan persentase jumlah serat yang lebih panjang dari $3 \mathrm{~mm}$.

Proses pembuatan pelat komposit PolyAlfiber selanjutnya akan menggunakan kemasan aseptik bekas melalui proses pencacahan (kode AS) tanpa proses penggilingan menggunakan blender (AB) sehingga diharapkan diperoleh komposisi serat dengan mayoritas serat panjang.

\section{Pembuatan Komposit PolyAl-fiber}

Pada penelitian ini telah dilakukan penelitian pembuatan komposit dengan bahan baku KBM yaitu dengan memanfaatkan secara langsung KBM sebagai sumber serat dan LDPE-Al yang telah dipisahkan sebagai polimer dan matriks logam. Pencampuran bahan yang telah dicacah secara homogen, kemudian dibuat pelat dengan mesin hot press sehingga diperoleh pelat komposit dengan bentuk dan permukaan sesuai cetakan. Penyediaan bahan yang mudah, dengan pembentukan komposit yang sederhana memberikan peluang dalam pemanfaatan limbah KBM.

Pada proses pembuatan papan komposit, plastik LDPE yang berasal dari bagian dalam KBM bersifat thermoplastik dan dapat meleleh pada suhu di atas $123^{\circ} \mathrm{C}$ (Polymer Properties Database, 2019; Sudiryanto, 2015). Dengan sifat ini, PE dari KBM dapat berfungsi sebagai perekat (binder/adhesif) yang meleleh pada saat hot press dengan suhu $165^{\circ} \mathrm{C}$. Sementara itu, bahan baku aluminium foil dapat berfungsi sebagai matriks dan serat dapat berfungsi sebagai bahan pengisi (filler) sehingga dengan pengepresan pada suhu tinggi kedua bahan baku tersebut dapat menghasilkan papan PolyAl-fiber yang kuat dan kompak.

Pembuatan komposit dari bahan baku yang melalui proses pencacahan dan hot press tanpa melalui proses peletisasi/molding, memberikan alternatif penyederhanaan penyediaan mesin untuk proses produksi. Diharapkan penyederhanaan proses ini dapat mempermudah dalam pemanfaatan KBM sebagai bahan komposit PolyAl-fiber, sehingga tujuan dalam rangka penanggulangan masalah limbah $\mathrm{KBM}$ dapat terlaksana.

\section{Karakteristik Komposit PolyAl-fiber}

Karakteristik produk berbentuk papan atau pelat komposit tercantum dalam persyaratan mutu produk. Parameter kadar air, daya serap air maksimum setelah perendaman, dan keteguhan lentur dan modulus elastisitas dipersyaratkan dalam Standar Nasional Indonesia (SNI) maupun standar Jepang (JIS) tentang mutu produk papan partikel (SNI 03-2105-2006 dan JIS A 5908:2003), papan serat (SNI 01-4449-2006 dan JIS A 5905:2003) dan komposit kayu plastic (SNI 8154:2015).

\section{Uji Bending}

Data hasil pengujian yang tercantum di dalam Tabel 3 memperlihatkan bahwa 
bending strength cenderung meningkat seiring dengan bertambahnya jumlah serat hingga $15 \%$, kemudian nilai tersebut akan cenderung menurun seiring penambahan serat hingga $30 \%$. Kecenderungan yang hampir serupa didapat pada nilai bending modulus, dimana sifat bending modulus cenderung meningkat seiring dengan panambahan jumlah serat hingga $15 \%$. Hal ini disebabkan karena penambahan serat sebagai filler dapat meningkatkan kekuatan sesuai sifat serat ataupun selulosa sebagai polimer pengikat kayu. Penambahan jumlah serat hingga 30\% tidak meningkatkan nilai bending modulus, yang justru cenderung menurun. Penurunan nilai bending modulus ini kemungkinan disebabkan oleh turunnya level binding pada komposit akibat menurunnya komposisi PE sebagai binder. Data rapat massa pada Tabel 3 memperlihatkan kecenderungan turunnya nilai rapat massa akibat turunnya level binding tersebut. Pelat komposit LDPE-Al dengan kandungan serat $15 \%$ menunjukkan nilai bending strength dan bending modulus tertinggi, yaitu 12,78 $\pm 0,60 \mathrm{MPa}$ untuk bending strength dan 1,16 $\pm 0,21 \mathrm{GPa}$ untuk bending modulus.

Peningkatan jumlah komposisi serat diperkirakan tidak akan meningkatkan nilai bending strength maupun bending modulus, dikarenakan nilai keduanya terus menurun seiring bertambahnya kandungan serat dari $15 \%$ menuju $30 \%$. Hasil ini serupa dengan hasil penelitian Ayrilmis, Kaymakci, Akbulut, and Mertoglu (2013) dan Sutivisedsak et al. (2012), dimana nilai bending strength ini akan menurun seiring dengan bertambahnya jumlah filler. Hal ini terjadi disebabkan oleh berkurangnya komponen binder pada komposit dan menggambarkan ketidakmampuan filler untuk mendukung penyaluran tegangan dari matriks (Ayrilmis et al., 2013). Sementara itu, nilai bending modulus akan meningkat seiring bertambahnya kandungan serat dari $5 \%$ menuju $15 \%$, nilai bending modulus ini akan mengalami kenaikan yang disebabkan oleh penurunan mobilitas rantai polimer akibat keberadaan filler (Ayrilmis et al., 2013). Hasil penelitian Soucy, Koubaa, Migneault, and Riedl (2014) lebih lanjut juga menyebutkan bahwa penambahan jumlah biomassa memang dapat meningkatkan kekuatan tarik dari komposit yang dihasilkan, namun juga dapat menurunkan tingkat plastisitas, regangan, dan rupture.

Bila dibandingkan dengan beberapa penelitian komposit yang menggunakan biomassa sebagai bahan bakunya (Ndububa, Nwobodo, and Okeh, 2015; Purwanto, 2016), nilai bending pada penelitian ini menunjukkan nilai yang lebih baik. Pada penelitian yang menggunakan bahan baku serat biomassa serutan rotan dan serat kayu dengan ditambah urea formaldehid $11 \%$ sebagai bonding menunjukkan nilai bending strength yang relatif lebih rendah dibandingkan penelitian ini. Hal ini kemungkinan karena rasio penambahan bahan bonding yang lebih sedikit dibandingkan jumlah serat dan matriks (Purwanto, 2016). Hal ini diperkuat oleh nilai rapat massa pada komposit hasil penelitian tersebut yang lebih rendah dari rapat massa penelitian ini (Tabel 3). Pada hasil penelitian Ndububa et al. (2015) yang menggunakan resin organik getah Arab sebagai resin, nilai bending strength nya jauh di bawah nilai yang dihasilkan dari produk komposit pada penelitian ini. Hal ini diperkirakan karena penelitian tersebut hanya menggunakan resin sebagai binder dengan persentasi di bawah 50\% (20-45\%), sehingga kekuatan dan rapat massa (Tabel 3) yang dihasilkan masih di bawah penelitian ini yang menggunakan PE sebagai binder paling sedikit 56\%. Alasan ini diperkuat dengan data pada penelitian yang sama yang menunjukkan bahwa kekuatan dan rapat massa terus meningkat seiring dengan bertambahnya komposisi resin getah Arab, dan nilai tersebut masih berpotensi dapat terus meningkat lagi dengan peningkatan komposisi resin di atas komposisi yang digunakan.

Bila dibandingkan dengan hasil penelitian komposit dengan bahan baku biomassa dan polyethylene, nilai bending strength penelitian ini berada di bawah hasil yang didapat pada penelitian Ayrilmis et al. (2013) yang menggunakan bahan baku campuran tepung sekam padi atau serbuk gergaji dengan polyethylene-aluminium melalui proses granulasi. Hasil dari penelitian tersebut berada pada kisaran 28,3-42,6 MPa untuk LDPEAl-serbuk gergaji dan 25,1-38,0 MPa untuk LDPE-Al-sekam padi. Namun, hasil penelitian yang sama juga menunjukkan nilai bending modulus yang lebih rendah dibandingkan penelitian ini, yaitu berada pada kisaran 3.1714.400 MPa untuk LDPE-Al-serbuk gergaji dan 2.493-3.360 MPa untuk LDPE-Al-sekam padi. Nilai bending strength yang lebih tinggi ini kemungkinan disebabkan oleh adanya maleic anhydrate (MA) seperti pada pembahasan sebelumnya (Ayrilmis et al., 2013) sehingga meningkatkan rapat massa (Tabel 3). Maleic 
anhydrate diketahui dapat berfungsi sebagai penambah rapat massa (Fathanah, 2011), sebagai compatibilizer, ataupun sebagai penurun kadar air dan meningkatkan ikatan internal antara bahan polimer dan serat, hal ini dikarenakan polimer thermoplastik adalah bahan bersifat non-polar dan menolak air yang tidak kompatibel dengan serat yang bersifat polar dan menyerap air (Fathanah, 2011; Nourbakhsh and Ashori, 2010)50/50, 25/75 and 0/100. Penambahan bahan aditif MA ini memang dapat meningkatkan ikatan antara PEAl-fiber, namun dengan harga yang relatif cukup mahal diperkirakan akan mengurangi tingkat ekonomis dari pelat komposit yang dihasilkan. Sementara itu, pada hasil penelitian Sutivisedsak et al. (2012), walaupun dengan kandungan LDPE hingga 90\%, nilai bending nya berada di bawah nilai bending komposit pada penelitian ini. Hal ini kemungkinan disebabkan oleh jenis serat yang berbeda serta ketiadaan pengaturan matriks pada penelitian tersebut.

Bila hasil penelitian ini dibandingkan dengan beberapa hasil penelitian komposit yang menggunakan limbah padat sebagai bahan bakunya, penelitian ini memperlihatkan nilai bending yang lebih baik. Hasil penelitian Rizaluddin and Setiawan (2019), yang menggunakan reject industri kertas memiliki nilai bending komposit yang lebih rendah walaupun sudah diberi tambahan MA dan pelet HDPE hingga rapat massanya di atas $0,8 \mathrm{~g} / \mathrm{cm}^{3}$ (Tabel 3). Hal ini kemungkinan disebabkan karena bahan baku reject industri kertas yang digunakan hanya berupa serat fine dengan panjang serat yang lebih rendah dan HDPE sebagai bonding, tanpa adanya pengaturan matriks. Hal ini yang menyebabkan nilai bending pada penelitian tersebut yang lebih rendah dibandingkan hasil penelitian ini. Pada hasil penelitian Soucy et al. (2014) yang menggunakan lumpur IPAL, didapatkan nilai bending yang lebih tinggi dibandingkan hasil penelitian ini. Seperti pada penjelasan pada alinea sebelumnya, hal ini kemungkinan disebabkan oleh adanya penambahan MA pada penelitian tersebut yang dapat meningkatkan ikatan internal.

Bila hasil penelitian ini dibandingkan dengan penelitian komposit yang menggunakan daur ulang KBM lain, antara hasil penelitian Hidalgosalazar et al. (2013) dan hasil penelitian Xiao and Qiu-hui (2013) memperlihatkan perbandingan nilai yang berbeda. Nilai bending modulus komposit dari hasil penelitian ini memiliki nilai yang lebih tinggi (pada 15\% kandungan serat) bila dibandingkan dengan hasil pada penelitian Hidalgo-salazar et al. (2013) yang tidak mengandung serat. Hal ini disebabkan karena nilai bending modulus ini akan mengalami kenaikan seiring dengan penambahan filler dikarenakan adanya penurunan mobilitas rantai polimer akibat keberadaan filler. Sementara pada penelitian Xiao and Qiu-hui (2013), papan partikel yang dihasilkan memang memiliki nilai bending strength dan bending modulus yang lebih tinggi, namun hal ini diduga disebabkan oleh penambahan resin sebagai bahan adhesif. Peningkatan kandungan resin yang memiliki fungsi sebagai binder tentunya akan secara langsung meningkatkan kekuatan komposit.

Berdasarkan SNI 8154:2015 mengenai komposit kayu plastik, keteguhan lentur (MOR) minimum 17,65 $\mathrm{MPa}$ dan modulus elastisitas lentur (MOE) minimum 1.961 MPa atau 1,96 Gpa. Bila nilai tersebut dibandingkan nilai bending strength dan bending modulus dapat disimpulkan bahwa sifat mekanis dari komposit yang dihasilkan masih di bawah standar dari komposit kayu plastik. Nilai ini juga masih di bawah nilai standar SNI dan JIS papan partikel untuk bending modulus, yaitu minimal 2,0 GPa, namun masih memenuhi persyaratan bending strength, yaitu dalam kisaran 8,0-18,04 MPa untuk SNI dan minimal 8,0 MPa untuk JIS. Menariknya, nilai komposit pada penelitian ini mayoritas memenuhi standar Jepang (JIS) papan serat, yaitu bending strength 5-30 MPa dan bending modulus 0,8-2,5 GPa (kecuali untuk $30 \%$ serat) untuk standar papan MDF. Untuk standar SNI papan serat, nilai bending komposit PolyAl-fiber berada di atas standar nilai papan serat kerapatan sedang (PSKS) sebesar 0,492,94 MPa untuk bending strength dan 0,078 GPa untuk bending modulus.

\section{Uji Daya Serap Air dan Kadar Air}

Hasil uji daya serap air dan kadar air dapat dilihat pada Tabel 3. Nilai hasil uji daya serap air dari tiga variasi kandungan serat $(0 \%, 10 \%$ dan 20\%) pada pelat komposit PolyAl-fiber menunjukkan penurunan bahwa nilai daya serat air terendah, yaitu $2,1 \%$ pada $0 \%$ serat, sedangan nilai tertinggi yaitu $14,1 \%$ berada pada kandungan serat paling besar $(20 \%)$. Ini mengindikasikan bahwa kandungan serat pada komposisi bahan pelat komposit akan memiliki pengaruh peningkatan daya serap air. Sifat selulosa 





yang higroskopis menyebabkan serat memiliki kemampuan untuk menyerap air sesuai dengan keadaan suhu dan kelembaban lingkungannya, terutama pada bagian selulosa yang amorphous (Kulasinski et al., 2014). Nilai daya serap air dapat menjadi bahan pertimbangan untuk aplikasi komposit pada lingkungan eksterior.

Nilai daya serap air ini lebih tinggi dibandingkan dengan penelitian Soucy et al. (2014). Hal ini disebabkan oleh penggunaan MA pada penelitian tersebut yang dapat menurunkan daya serap air dikarenakan adanya peningkatan kompatibilitas (Soucy et al., 2014). Maleic anhydrate diketahui dapat berfungsi sebagai penambah rapat massa, compatibilizer, ataupun sebagai penurun kadar air dan meningkatkan ikatan internal antara polimer termoplastik dan serat (Fathanah, 2011; Nourbakhsh and Ashori, 2010). Hasil penelitian Nurhidayat and Wijoyo (2014) juga memperlihatkan nilai daya serap air yang lebih kecil dibandingkan dengan hasil penelitian ini, yaitu mencapai $0,01 \%$. Hal ini kemungkinan karena hasil penelitian tersebut menggunakan proses perlakuan yang berbeda serta penggunaan HDPE dengan proporsi yang lebih banyak (hingga 90\%). Pada penelitian tersebut bahan baku komposit selain dijemur di bawah sinar matahari, juga melalui dua kali proses oven $\left(110^{\circ} \mathrm{C}\right.$ dan $\left.60^{\circ} \mathrm{C}\right)$ sebelum proses hot press pada suhu $120^{\circ} \mathrm{C}$. Bila dibandingkan dengan Papan Serat (PSKT Tipe 1.20 tebal $<3,5$ $\mathrm{mm}$ ), daya serap air komposit PolyAl-fiber ini dapat memenuhi persyaratan.

Dibandingkan dengan hasil penelitian Xiao and Qiu-hui (2013), hasil penelitian ini memiliki nilai kadar air yang lebih kecil walaupun penelitian tersebut telah ditambahkan waterproof agent. Hal ini dikarenakan karena kandungan biomassa yang lebih tinggi pada komposit hasil penelitian tersebut, yaitu hingga $60 \%$. Sehingga dengan ketebalan sampai dengan $8 \mathrm{~mm}$ dan sifat biomassa serbuk gergaji tersebut yang higroskopis tentunya akan meningkatkan nilai kadar air (Xiao and Qiu-hui, 2013). Hal yang sama terlihat pada hasil penelitian Rizaluddin and Setiawan (2019) dan hasil penelitian Purwanto (2016) yang kompositnya (relatif) memiliki nilai kadar air lebih besar dibandingkan komposit hasil penelitian ini. Kadar kandungan serat yang lebih banyak menjadi penyebab besarnya kadar air pada komposit hasil kedua penelitian tersebut. Kadar serat pada komposit hasil penelitian Rizaluddin and Setiawan (2019) mencapai 50,75\%, sedangkan pada hasil penelitian Purwanto (2016) mencapai $89 \%$.

Bila dibandingkan dengan nilai SNI papan partikel, SNI papan serat dan SNI komposit kayu plastik, nilai hasil uji kadar air pelat komposit PolyAl-fiber memenuhi persyaratan ketiga standar tersebut. Kualitas kadar air yang rendah pada komposit PolyAl-fiber hasil percobaan menunjukkan potensi pemanfaatan sebagai pengganti papan partikel, papan serat, maupun komposit kayu plastik.

Pada dasarnya, selain dipengaruhi oleh rapat massa, nilai swelling juga dapat dipengaruhi oleh kadar air. Peningkatan nilai kadar air dapat diikuti dengan peningkatan volume. Berdasarkan analisis pada nilai bending strength, diperkirakan kandungan serat $15 \%$ merupakan nilai optimal pada penelitian ini karena pelat komposit dengan kandungan serat lebih besar (20-30\%) akan memiliki nilai swelling (akibat kandungan air dan rapat massa) yang lebih besar pula. Hasil ini senada dengan hasil yang didapat pada penelitianpenelitian lain sebelumnya (Khazraji and Robert, 2013; Rachtanapun, Sattayarak, and Ketsamak, 2012; Soucy et al., 2014).

\section{Uji Tebal dan Rapat Massa}

Dari data pada Tabel 3, terlihat bahwa penambahan serat ke dalam komposit meningkatkan ketebalan komposit. Semakin banyak serat yang ditambahkan, semakin tinggi ketebalan komposit. Dari sisi rapat massa, penambahan serat ke dalam komposit menyebabkan komposit per satuan volume menjadi menjadi lebih ringan. Hal ini sesuai dengan karakteristik serat yang bersifat bulky sehingga komposit PolyAl-fiber yang dihasilkan menjadi lebih bulky, lebih tebal namun dengan kerapatan yang lebih kecil. Hal senada juga ditunjukkan pada hasil penelitian Nurhidayat and Wijoyo (2014), yang menyatakan bahwa tingkat rapat massa akan cenderung menurun dengan bertambahnya kandungan serat. Namun, hal yang berbeda ditunjukkan oleh hasil penelitian Ayrilmis et al. (2013), di mana terdapat peningkatan rapat massa ketika terjadi penambahan serat. Hal ini juga diperkirakan terjadi karena adanya penambahan MA yang berakibat meningkatnya kompatibilitas bahan baku.

Nilai rapat massa komposit yang dihasilkan berada di atas papan serat yang terbuat dari biomassa serutan rotan dan serbuk kayu hasil 
kajian Purwanto (2016), hal ini disebabkan oleh penambahan aditif urea formaldehid yang cukup rendah sebanyak $11 \%$ dan tekanan yang diberikan hanya 16 dan tebal yang hanya $1 \mathrm{~cm}$. Nilai rapat massa ini berada di bawah nilai yang didapatkan pada hasil penelitian Ayrilmis et al. (2013) yang mendapatkan nilai $1,12-1,15 \mathrm{~g} / \mathrm{cm}^{3}$ untuk polyethylene-aluminium-serbuk gergaji dan $1,14-1,15 \mathrm{~g} / \mathrm{cm}^{3}$ untuk polyethylene-aluminiumsekam padi dengan tebal pelat $3,2 \mathrm{~mm}$. Hal ini diperkirakan karena adanya penambahan MA dan proses peletisasi pada penelitian tersebut yang dapat menyebabkan komposit menjadi lebih kompak. Terlihat pada Tabel 3 bahwa penambahan MA pada penelitian tersebut tampak menonjol sendiri dengan kerapatan paling tinggi dengan nilai kerapatan di atas $1 \mathrm{~g} / \mathrm{cm}^{3}$. Sementara itu, data dari hasil penelitian Ndububa et al. (2015) dan hasil penelitian Nurhidayat and Wijoyo (2014), menunjukkan nilai rapat massa yang berada di bawah nilai rapat massa hasil penelitian ini. Pada hasil penelitian Ndububa et al. (2015), hal tersebut kemungkinan disebabkan oleh penambahan resin yang masih di bawah 50\% (20-45\%). Hasil penelitian tersebut menunjukkan bahwa rapat massa akan semakin meningkatnya seiring dengan bertambahnya komposisi resin getah Arab, dan nilai tersebut masih berpotensi meningkat lagi dengan peningkatan komposisi resin (data tidak ditunjukkan pada naskah ini). Pada hasil penelitian Nurhidayat and Wijoyo (2014), rendahnya nilai rapat massa kemungkinan disebabkan oleh bahan baku yang lebih bulky. Hal tersebut diindikasikan oleh data pada penelitian tersebut yang menunjukkan peningkatan rapat massa yang sedikit walaupun kandungan serat dikurangi dari 50\% menjadi $10 \%$ (data tidak ditunjukkan pada naskah ini). Pada hasil penelitian Rizaluddin and Setiawan (2019), komposit yang dihasilkan memiliki nilai rapat massa yang lebih tinggi, hal ini kemungkinan disebabkan oleh penambahan MA hingga 10\% dan pelet HDPE (tambahan) hingga 9\% yang memungkinkan terjadinya kerapatan yang lebih tinggi.

Berdasarkan klasifikasi SNI 01-4449-2006 tentang papan serat, komposit murni LDPE-Al termasuk dalam kategori kerapatan tinggi $(>0,84$ $\mathrm{g} / \mathrm{cm}^{3}$ ), sedangkan komposit PolyAl-fiber yang mengandung serat termasuk dalam kategori kerapatan sedang $\left(0,40-0,84 \mathrm{~g} / \mathrm{cm}^{3}\right)$. SNI yang sama juga mengatur toleransi tebal untuk kedua klasifikasi papan tersebut, standar toleransi untuk papan kerapatan tinggi yang berada pada kelas ketebalan $\leq 3,5 \mathrm{~mm}$ adalah $\pm 0,4 \mathrm{~mm}$, sedangkan untuk kerapatan sedang yang berada pada kelas $<7 \mathrm{~mm}$ toleransi tebalnya sebesar $\pm 0,5 \mathrm{~mm}$. Selain itu, komposit PolyAl-fiber yang dihasilkan juga memenuhi nilai standar rapat massa untuk standar papan partikel (SNI dan JIS) dan juga SNI komposit kayu plastik.

\section{Uji Flammability}

Hasil uji flammability dapat dilihat pada Tabel 4, Nilai hasil uji flammability dari tiga variasi kandungan serat $(0 \%, 10 \%$ dan $20 \%)$ pada pelat komposit PolyAl-fiber menunjukkan penurunan nilaiflammability. Ini mengindikasikan bahwa kandungan serat sampai $20 \%$ berpengaruh terhadap penurunan sifat flammability pelat komposit. Nilai hasil uji flammability pelat komposit PolyAl-fiber berkisar pada nilai 3,0$3,2 \mathrm{~cm} /$ menit. Fenomena ini serupa dengan hasil penelitian Obidiegwu (2012), bahwa semain banyak serat yang ditambahkan maka semakin kecil nilai flammability dari komposit. Hal ini kemungkinan disebabkan oleh adanya kandungan oksigen, nitrogen dan abu dalam serat yang dapat menyebabkan penurunan nilai heating dan flammability. Nilai flammability ini jauh lebih baik dari biomassa, seperti pada hasil penelitian Bharath and Basavarajappa (2014), dan mendekati nilai flammability dari PVC dan PP.

\section{Analisa Hasil Uji Komposit PolyAl-fiber}

Berdasarkan penelitian ini, komposit PolyAlfiber memiliki karakteristik yang sudah dapat memenuhi nilai standar SNI dan JIS. Komposit PolyAl-fiber ini sudah dapat memenuhi standar SNI dan JIS untuk produk PSKS/MDF, namun masih belum memenuhi nilai standar komposit kayu plastik, dan masih perlu meningkatkan nilai bending strength dan bending modulus nya. Kualitas komposit PolyAl-fiber ini juga cukup bersaing dengan produk sejenis, terutama mengingat komposit ini tidak menggunakan pretreatment ataupun tambahan bahan baku lain (aditif, MA, dll). Produk komposit PolyAl-fiber ini hanya melalui proses hot press dengan bahan baku PolyAl-fiber hasil daur ulang KBM tanpa penambahan bahan maupun proses lain sehingga diperkirakan dapat menyederhanakan proses dengan hasil yang tidak jauh berbeda atau lebih baik. 
Tabel 4. Hasil Uji Flammability dari Pelat Komposit PolyAl-fiber dibandingkan dengan SNI dan Penelitian Sejenis

\begin{tabular}{|c|c|c|c|c|}
\hline No & $\begin{array}{l}\text { Komposisi bahan } \\
\text { Pelat komposit }\end{array}$ & $\begin{array}{c}\text { Flammability } \\
\text { (cm/menit) }\end{array}$ & Keterangan & Literatur \\
\hline 1 & LDPE-Al 100\% & $3,2 \pm 0,32$ & & \\
\hline 2 & $10 \%$ Serat $-90 \%$ LDPE-Al & $3,15 \pm 0,06$ & & \\
\hline 3 & $20 \%$ Serat $-80 \%$ LDPE-Al & $2,99 \pm 0,23$ & & \\
\hline \multicolumn{2}{|c|}{ Serat kain woven } & $2,4-19,4$ & $\begin{array}{l}\text { Ditambah fire } \\
\text { retardant } 10,1-12,1 \%\end{array}$ & $\begin{array}{c}\text { Pornwannachai, } \\
\text { Ebdon, and Kandola } \\
\text { (2018) }\end{array}$ \\
\hline \multicolumn{2}{|c|}{ Poli Vinil Klorida (PVC) } & 2,9 & & Bhattacharjee, Sazzad, \\
\hline \multicolumn{2}{|c|}{ Poli propilen (PP) } & 3,4 & & $\begin{array}{l}\text { Islam, Ahtashom, and } \\
\text { Miah, (2013) }\end{array}$ \\
\hline \multicolumn{2}{|c|}{ Serat dari kulit batang kelapa } & $40-53$ & & $\begin{array}{c}\text { Bharath and } \\
\text { Basavarajappa (2014) }\end{array}$ \\
\hline \multicolumn{2}{|c|}{$\begin{array}{l}5-20 \% \text { Kulit batang kacang kola - } \\
\text { 95-80\% HDPE }\end{array}$} & $0,23-0,70$ & & Obidiegwu (2012) \\
\hline \multicolumn{2}{|c|}{$\begin{array}{l}\text { 5-20\% Kulit batang Alstonia } \\
\text { boonei-95-80\% HDPE }\end{array}$} & $0,35-0,59$ & & \\
\hline
\end{tabular}

\section{Kesimpulan}

Hasil komposit PolyAl-fiber dengan kandungan serat $15 \%$ memiliki nilai bending strength tertinggi, yaitu $12,78 \mathrm{MPa}$, dengan nilai bending modulus 11,60 GPa dan flammability sebesar $3 \mathrm{~cm} /$ menit. Komposit PolyAl-fiber dengan kandungan serat $10-20 \%$ memiliki nilai daya serap air $12,6-14,1 \%$, kadar air 1,6-1,9\% dan nilai rapat massa $0,75-0,79 \mathrm{~g} / \mathrm{cm}^{3}$, pada ketebalan 2,9-3,1 mm. Nilai bending strength komposit tersebut berada pada rentang standar SNI dan JIS untuk papan partikel serta JIS untuk papan serat, sedangkan nilai bending modulus berada pada rentang yang ditentukan untuk SNI dan JIS papan serat jenis PSKS/MDF. Bila dibandingkan dengan SNI komposit kayu plastik, nilai tersebut berada di bawah nilai yang ditentukan. Nilai kadar air dan nilai rapat massa dari papan PolyAlfiber telah memenuhi syarat SNI dan JIS papan partikel, SNI dan JIS papan serat (PSKS/MDF), maupun SNI komposit kayu plastik.

Komposit yang terbuat dari proses hot press dengan bahan baku PolyAl-fiber hasil daur ulang KBM tanpa penambahan bahan maupun proses lain, memiliki karakteristik yang dapat memenuhi beberapa kriteria standar jenis produk seperti PSKS/MDF, beberapa standar papan partikel, dan beberapa standar komposit kayu plastik. Produk komposit yang dihasilkan juga diperkirakan dapat lebih fleksibel, lebih tahan air dan lebih tahan api bila dibandingkan dengan produk yang terbuat dari bahan baku kayu atau biomassa. Dari sisi lingkungan, komposit yang terbuat dari proses hot press, yang seluruh bahan bakunya (PE-Al-fiber) berasal dari hasil daur ulang KBM, diperkirakan akan dapat membantu pengelolaan limbah KBM dan membantu produsen dalam melengkapi proses sirkular ekonominya serta memiliki kesan (image) yang lebih baik karena berasal dari daur ulang. Selain itu, produk komposit ini juga akan lebih tahan rayap dan relatif tidak memerlukan bahan pengawet sehingga dapat dikatakan relatif lebih ramah lingkungan.

\section{Ucapan Terima Kasih}

Puji dan syukur dipanjatkan kehadirat Allah SWT yang telah melimpahkan rahmat dan karunia-Nya, kami sampaikan terima kasih kepada semua pihak yang turut berperan dalam pelaksanaan kegiatan, antara lain Andoyo Sugiharto selaku Kepala BBPK periode tahun 2019, Saiful Bahri selaku Kepala BBPK, Togu Sihombing, Hr. Judi Tjahjono, Lies Indriati, dan Nina Elyani atas fasilitas dan bimbingan yang 
telah diberikan, dan anggota tim peneliti yang telah bekerja dengan optimal sehingga tujuan dari penelitian ini dapat tercapai, serta seluruh pihak yang telah membantu yang tidak dapat disebutkan satu per satu.

\section{Daftar Pustaka}

Ayrilmis, N., Kaymakci, A., Akbulut, T., and Mertoglu, G. (2013). Composites : Part B Mechanical Performance of Composites Based on Wastes of Polyethylene Aluminum and Lignocellulosics. Composites Part $B$ 47(April), 150-154. https://doi. org/10.1016/j.compositesb.2012.10.019

Bharath, K. N., and Basavarajappa, S. (2014). Flammability Characteristics of Chemical Treated Woven Natural Fabric Reinforced Phenol Formaldehyde Composites. Procedia Materials Science, 5, 1880-1886. https://doi.org/10.1016/j. mspro.2014.07.507

Bhattacharjee, S., Sazzad, M. H., Islam, M. A., Ahtashom, M. M., and Miah, M. Y. (2013). Effects of Fire Retardants on Jute Fiber Reinforced Polyvinyl Chloride/ Polypropylene Hybrid Composites. International Journal of Materials Science and Applications, 2(5), 162-167. https://doi. org/10.11648/j.ijmsa.20130205.13

Ezekwem, D. (2016). Composite Materials Literature review for Car bumber. https://doi. org/10.13140/RG.2.1.1817.3683

Fathanah, U. (2011). Kualitas Papan Komposit dari Sekam Padi dan Plastik HDPE Daur Ulang Menggunakan Maleic Anhydride (MAH) sebagai Compatibilizer. Jurnal Rekayasa Kimia Dan Lingkungan, 8(2), 53-59. Retrieved from http://www.jurnal. unsyiah.ac.id/RKL/article/view/741

Feldbauer, A. (2014). University of Applied Sciences Upper Austria Analysis and reduction of wastewater loads of a paper plant for the production of medical and hygiene products, 2012.

Hidalgo-salazar, M. A., Mina, J. H., and Herrerafranco, P. J. (2013). Composites : Part $B$ The Effect of Interfacial Adhesion on the Creep Behaviour of LDPE-Al-Fique Composite Materials. Composites Part $B$, 55(December), 345-351. https://doi. org/10.1016/j.compositesb.2013.06.032

Indonesia Finance Today. (2014). Industri Pulp dan Kertas Diproyeksi Tumbuh 12\% Tahun Depan. Retrieved December 20, 2019, from https://kemenperin.go.id/artikel/10740/ Industri-Pulp-dan-Kertas-DiproyeksiTumbuh-12-Tahun-Depan
Iswanto, A. H., Febrianto, F., Hadi, Y. S., and Ruhendi, S. (2013). The Effect of Pressing Temperature and Time on the Quality of Particle Board Made from Jatropha Fruit Hulls Treated in Acidic Condition, 17(3), 145-151. https://doi.org/10.7454/mst.v17i3.2930

Khazraji, A. C., and Robert, S. (2013). Interaction Effects between Cellulose and Water in Nanocrystalline and Amorphous Regions : A Novel Approach Using Molecular Modeling. Journal of Nanomaterials, 2013(Article ID 409676). https://doi.org/https://doi. org $/ 10.1155 / 2013 / 409676$

Kulasinski, K., Keten, S., Churakov, S. V, Guyer, R., Carmeliet, J., and Derome, D. (2014). Molecular Mechanism of Moisture-Induced Transition in Amorphous Cellulose. ACS Macro Letters, 3(10), 1037-1040. https:// doi.org/https://doi.org/10.1021/mz500528m

Media Indonesia. (2019). 10.388 Ton Kemasan Karton Bekas Minuman dan Makanan Didaur Ulang. Retrieved June 19, 2020, from https://mediaindonesia.com/read/ detai1/258291-10388-ton-kemasan-kartonbekas-minuman-dan-makanan-didaur-ulang

Molina Grima, E., Belarbi, E. H., Acién Fernández, F. G., Robles Medina, A., and Chisti, Y. (2003). Recovery of microalgal biomass and metabolites: Process options and economics. Biotechnology Advances, 20(7-8), 491-515. https://doi.org/10.1016/ S0734-9750(02)00050-2

Ndububa, E. E., Nwobodo, D. C., and Okeh, I. M. (2015). Mechanical Strength of Particleboard Produced from Fonio Husk with Gum Arabic Resin Adhesive as Binder. Journal of Engineering Research and Applications, 5(4), 29-33.

Nourbakhsh, A., and Ashori, A. (2010). Particleboard Made from Waste Paper Treated with Maleic Anhydride. Waste Management \& Research, 28(1), 51-55. https://doi.org/10.1177/0734242X09336463

Nurhidayat, A., and Wijoyo. (2014). Pengaruh Fraksi Volume Serat Cantula Terhadap Ketangguhan Impak Komposit CantulaHDPE Daur Ulang Sebagai Bahan Core Lantai Ramah Lingkungan. In Fakultas Teknik Universitas Muria Kudus (Ed.), Prosiding Seminar Nasional Teknologi dan Informatika (SNATIF) Ke 1, Universitas Muria Kudus, 2014 (pp. 145-152). Fakultas Teknik Universitas Muria Kudus. Retrieved from https://jurnal.umk.ac.id/index.php/ SNA/issue/view/24

Obidiegwu, M. U. (2012). Flammability Properties of Low Density Polyethylene/ Wood Fibre Composites. IOSR Journal of Engineering, 2(4), 777-780. 
Polymer Properties Database. (2019). LowDensity Polyethylene (LDPE). Retrieved June 21, 2020, from https://polymerdatabase. com/Commercial Polymers/LDPE.html

Pornwannachai, W., Ebdon, J. R., and Kandola, B. K. (2018). Fire-Resistant Natural Fibre-Reinforced Composites from Flame Retarded Textiles. Polymer Degradation and Stability, 154(August), 115-123. https://doi. org/10.1016/j.polymdegradstab.2018.05.019

Purwanto, D. (2016). Sifat Fisis dan Mekanis Papan Partikel dari Limbah Campuran Serutan Rotan dan Sebuk Kayu. Jurnal Riset Industri, 10(3), 125-133.

Rachtanapun, P., Sattayarak, T., and Ketsamak, N. (2012). Correlation of density and properties of particleboard from coffee waste with urea - formaldehyde and polymeric methylene diphenyl diisocyanates. Journal of Composite Materials, 46(15), 1839-1850. https://doi.org/10.1177/0021998311426624

Rini, A. S. (2019). Industri pulp dan kertas Indonesia Masuk 10 Besar Dunia. Retrieved December 20, 2019, from https://ekonomi. bisnis.com/read/20190127/257/882862/ industri-pulp-dan-kertas-indonesia-masuk10-besar-dunia

Rizaluddin, A. T., Rostika, I., and Wattimena, R. B. I. (2020). Progress of used beverages carton recycling system in Indonesia : A review Progress of used beverages carton recycling system in Indonesia: A review. In IOP Conference Series: Earth and Environmental Science. https://doi. org/10.1088/1755-1315/483/1/012013

Rizaluddin, A. T., and Setiawan, Y. (2019). Potency to Recycle Hydrapulper Reject Waste of Paper Mill into Composite Particleboard. Jurnal Riset Teknologi Pencegahan Pencemaran Industri, 10(1), 1-11. $\quad$ https://doi.org/https://10.21771/ jrtppi.2019.v10.no.1.p1-11

Soucy, J., Koubaa, A., Migneault, S., and Riedl, B. (2014). The Potential of Paper Mill Sludge for Wood-Plastic Composites. Industrial Crops and Products Products, 54(Maret), 248-256. https://doi.org/10.1016/j. indcrop.2014.01.013
Sudiryanto, G. (2015). Pengaruh Suhu dan Waktu Pengempaan Terhadap Sifat Fisik dan Mekanik Papan Partikel Kayu Sengon (Paraserienthes Falcataria ( L ) Nielson). DISPROTEK, 6(1), 67-74.

Sulaiman, M., and Rahmat, M. H. (2018). Kajian Potensi Pengembangan Material Komposit Polimer dengan Serat Alam untuk Produk Otomotif. In Seminar Nasional Teknik Mesin (SISTEM). Jember: Teknik Mesin Universitas Jember.

Sutivisedsak, N., Cheng, H. N., Burks, C. S., Johnson, J. A., Siegel, J. P., Civerolo, E. L., and Biswas, A. (2012). Use of Nutshells as Fillers in Polymer Composites. Journal of Polymers and the Environment, 20(2), 305314. https://doi.org/10.1007/s10924-0120420-y

Tetra Pak. (2020a). Apa Yang Dimaksud Dengan Teknologi UHT? Retrieved January 29, 2020, from https://www.tetrapak.com/id/ about/teknologi-uht

Tetra Pak. (2020b). Daur Ulang Investasi untuk Masa Depan. Retrieved January 29, 2020, from https://www.tetrapak.com/id/ sustainability/daur-ulang-kemasan

Uitterhaegen, E., Nguyen, Q. H., Merah, O., Stevens, C. V., Talou, T., Rigal, L., and Evon, P. (2016). New Renewable and Biodegradable Fiberboards from a Coriander Press Cake. Journal of Renewable Materials, 4(3), 225-238. https://doi.org/10.7569/ JRM.2015.634120

Xiao, S., and Qiu-hui, Z. (2013). Study on the Optimum Hot-Pressing Process and Surface Decoration of Waste Tetra Pak/ Sawdust Composite Board. Advanced Materials Research, 710(June), 147-151. https://doi.org/10.4028/www.scientific.net/ AMR.710.147 
Lurnal Selulosa, Vol. 10, No. 1, Juni 2020:21 - 34

- Halaman ini sengaja dikosongkan - 